\title{
Relationships between Antarctic sea-ice and South African winter rainfall
}

\author{
R. Blamey, C. J. C. Reason* \\ Department of Oceanography, University of Cape Town, Private Bag X3, Rondebosch 7701, South Africa
}

\begin{abstract}
Evidence is presented of a statistical relationship between anomalies in winter sea-ice over the South Atlantic sector of the Antarctic and winter rainfall over western South Africa. A positive (negative) correlation exists between sea-ice concentration over the Weddell Sea/Drake Passage region (east of the Weddell Sea from 0 to $30^{\circ} \mathrm{E}$ ) and rainfall between May and September. When broken down into early, mid and late winter, the relationships appear stronger for early (May to July) and mid (June to August) winter than for late (July to September) winter and the month of July. In all cases, the relationships occur at 1 to 2 mo lead, suggesting that some predictability of winter rainfall may exist based on sea-ice concentration found earlier in the season. Analysis of circulation patterns associated with anomalously wet and dry winters from 1982 to 2004 indicates that the former are characterised by a cyclonic anomaly over southern South Africa that stretches southwest over the mid-latitude South Atlantic. In addition, there are increases in low level westerly moisture flux, and enhanced uplift, relative cyclonic vorticity and convergence over and upstream of the region. These patterns, combined with evidence of a northward shifted and more intense subtropical jet, indicate that the mid-latitude storm track is located anomalously far north during wet winters and that the cold fronts, which climatologically bring most of the annual rainfall, are likely to intensify just upstream of southwestern South Africa.
\end{abstract}

KEY WORDS: South African Climate $\cdot$ Antarctic sea-ice

\section{INTRODUCTION}

The western, coastal region of South Africa (30 to $34.5^{\circ} \mathrm{S}, 17$ to $20^{\circ} \mathrm{E}$ ) receives most of its rainfall during the austral winter. Other parts of subtropical southern Africa are mainly characterised by summer rainfall. Despite the importance of the winter rainfall to the local economy and its pronounced interannual variability (Reason et al. 2002), relatively little research on the climate of the region has been conducted. Most of the winter rainfall is produced by cold fronts and associated extratropical cyclones, but other westerly disturbances, such as cut-off lows, may on occasion also produce significant rainfall over the region (Singleton \& Reason 2006, 2007). Reason et al. (2002) suggested that the considerable interannual variability of the winter rainfall may be influenced by sea-surface temperatures (SST) in the subtropical to mid-latitude
South Atlantic, a suggestion supported by the results of atmospheric model experiments forced by idealised SST anomalies in this region (Reason \& Jagadheesha 2005).

Relatively little study of the relationships between the Antarctic region and South African climate has been conducted, despite the fact that Antarctica plays an important role in the global climate system (e.g. Wadhams 1994, de la Mare 1997, Yuan \& Martinson 2000). Hudson \& Hewitson (2001) performed idealised atmospheric general circulation experiments with reduced Antarctic sea-ice, and found an increase in surface pressure and decrease in mid-latitude cyclones in the band between 30 and $50^{\circ} \mathrm{S}$. Reason \& Rouault (2005) showed that a relationship exists between the Antarctic Oscillation/Southern Annular Mode and winter rainfall over western South Africa. The open ocean area between Antarctica and the other southern hemispheric landmasses, with associated Antarctic Cir- 
cumpolar Current and atmospheric westerlies, facilitates interaction between atmospheric and oceanic circulation in the mid to high latitudes (White \& Peterson 1996, Reason 2000, Renwick 2002) as well as the transmission of mid-latitude climate anomalies around the hemisphere. The most obvious example of the latter is the Antarctic Circumpolar Wave (White \& Peterson 1996). As yet, no clear evidence of the influence of this phenomenon on South African climate has been found; however, there are indications that it affects the climate of Gough and Marion Islands located near $40^{\circ} \mathrm{S}$ and $48^{\circ} \mathrm{S}$ in the southeast Atlantic and southwest Indian Oceans respectively (Melice et al. 2005).

In terms of seasonal variability, most calculations of sea-ice extent vary from a minimum of 3 to 5 million $\mathrm{km}^{2}$ in February to a maximum of 17 to 20 million $\mathrm{km}^{2}$ in September (Peixoto \& Oort 1992, Wadhams 1994, Godfred-Spenning \& Simmonds 1996, Eicken \& Lemke 2001). However, the lack of reliable long-term data for Antarctic sea-ice is problematic for studies of Southern Hemisphere climate variability. Satellite data available since the late 1970s has resulted in increased observations and coverage of remote areas in the Southern Hemisphere. Other Antarctic sea-ice data sets that extend back before the 1970s are based on other sources, such as whaling records (e.g. de la Mare 1997), but these data sets have gaps in both space and time and tend to be derived from specific areas.

In this study, relationships between variability in Antarctic sea-ice concentration and South African winter rainfall are examined. With the exception of the idealised modelling study of Hudson \& Hewitson (2001), we are not aware of any research that specifically examines the potential influence of Antarctic sea-ice variability on South African climate.

A description of data and analytical methods is found in Section 2. The results are presented in Section 3, while Section 4 covers the possible links between seaice concentration and rainfall over western South Africa. Sections 5 and 6 contain a discussion and the conclusions, respectively.

\section{DATA AND METHODOLOGY}

Reynold's Optimally Interpolated (OI) version 2 seaice data (Reynolds \& Smith 1994, Reynolds et al. 2002), available from 1982, were used to assess anomalies in sea-ice concentration, which is determined as the percentage of area covered by sea-ice in a given $1^{\circ} \times 1^{\circ}$ grid box. South African Weather Service (SAWS) gridded rainfall data spatially averaged from the west coast to the interior plateau were used to form an index of winter rainfall. A criterion of at least $1 \mathrm{SD}$ from the mean was used to determine anomalously wet and dry winters during the period of overlap of the 2 data sets (1982 to 2004).

Potential relationships between sea-ice and winter rainfall were examined using correlations (de-trended) for the entire season (May to September) and for the early (May to July), mid (June to August) and late (July to September) winter periods, as well as for individual months. Atmospheric circulation patterns during anomalously wet and dry winters were examined using NCEP-NCAR re-analysis data (Kalnay et al. 1996). These data are available at a $2.5^{\circ}$ horizontal resolution and have been widely used to analyse the climate variability of the South Atlantic and southern African regions (e.g. Sterl \& Hazeleger 2003, Melice et al. 2005, Reason \& Rouault 2005). Tennant (2004) provided evidence that the interannual variability in the re-analyses over the region prior to 1979 is reduced compared with the post-1979 period as a result of the introduction of satellite data in 1978. Note, however, that we only consider the 1982 to 2004 period, as this corresponds to the availability of the sea-ice data.

\section{RELATIONSHIP BETWEEN ANOMALIES IN SEA-ICE AND RAINFALL}

Winter rainfall over western South Africa displays considerable interannual variability (Fig. 1). Using a criterion of 1 SD from the mean, Fig. 1 indicates that 1983, 1986, 1987, 1991, 1996 and 2001 may be considered anomalously wet and 1982, 1988, 1999, 2000, 2003 and 2004 anomalously dry.

Also illustrated in Fig. 1 are anomalies in sea-ice concentration averaged over the eastern Weddell Sea region $\left(0\right.$ to $30^{\circ} \mathrm{E}, 55$ to $\left.65^{\circ} \mathrm{S}\right)$. As will be shown later, this region exhibits a relatively strong relationship with rainfall. Of the $23 \mathrm{yr}$ of data, 19 winters show an opposite-signed anomaly between sea-ice concentration in this region and winter rainfall over western South Africa. However, although the 2 series are correlated at $r=-0.66(p<0.005)$, Fig. 1 suggests that the magnitude of the rainfall anomaly is not always strongly related to that of sea-ice. This result suggests that there are other factors that influence the rainfall, such as SST anomalies in the South Atlantic (Reason \& Jagadheesha 2005).

To examine relationships between the winter rainfall and sea-ice concentration, correlations between these 2 variables were initially performed for the winter as a whole (May-September; Fig. 2). The left column in Fig. 2 shows the correlation coefficients, whereas the right column plots areas where these are statistically significant at levels ranging from 90 to $99.9 \%$. At zero lag (Fig. 2a), there is a strong negative (positive) correlation between winter rainfall and sea-ice concentra- 


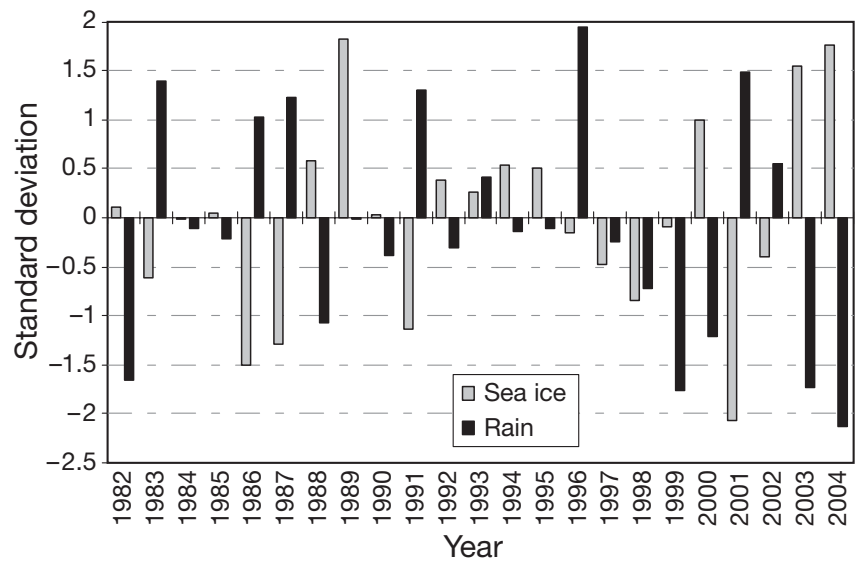

Fig. 1. Time series of standardised anomalies in winter (May to September), Reynold's sea-ice concentration (Reynolds et al. 2002) averaged over 55 to $65^{\circ} \mathrm{S}, 0$ to $30^{\circ} \mathrm{E}$ (grey bars), and rainfall averaged over western South Africa using South African Weather Service gridded data (black bars)

tion near the region between 0 and $30^{\circ} \mathrm{E}$ (in the Weddell Sea region and to the west of the Antarctic Peninsula). Correlation coefficients range from 0.3 to 0.5 in the Weddell Sea and from -0.5 to -0.7 near the 0 to $30^{\circ} \mathrm{E}$ band, indicating that the inverse relationship with rainfall is stronger in the latter region. Similar correlation patterns were found between sea-ice and rainfall lagging by 1 and 2 mo; however, the positive regions in the Weddell Sea weaken substantially more than the area of negative correlation (Fig. 2b,c). Relatively strong negative correlations in this 0 to $30^{\circ} \mathrm{E}$ area are still evident at 5 mo lag. These results suggest that there may be some predictability of the sign of the winter rainfall anomaly over western South Africa, based on sea-ice concentration in the preceding late summer or autumn. The significance plots suggest that the contrasting pattern of positive and negative relationships in the Weddell Sea/Antarctic Peninsula and 0 to $30^{\circ} \mathrm{E}$ regions is robust.

To test this further, correlation analyses for early (May to July), mid (June to August) and late (July to September) winter were performed (not shown). The marked contrasting areas of positive/negative distribution were present in all cases (not shown), with the correlations being stronger in early and mid-winter than in late winter. When the process was repeated for individual months, the strongest relationships were obtained for July (not shown). Taken together, the correlation results suggest that some indications of winter rainfall, either at a semiannual, seasonal, or monthly scale, may be obtained from sea-ice concentration at least 1 to 2 mo in advance, and in some cases longer. This suggestion is supported by the study of Simmonds \& Jacka (1995) who found evidence of delayed impacts of sea-ice on regional climate, thus leading to a lagged relationship between sea-ice concentration and rainfall.

\section{POTENTIAL MECHANISMS}

Most of the rainfall over western South Africa results from cold fronts, with the parent depressions located south of South Africa (Tyson \& Preston-Whyte 2000). Cut-off lows can also provide significant contributions to winter rainfall; however, because they generally occur less frequently than fronts, their contribution to the seasonal rainfall total tends to be less on average (Singleton \& Reason 2006, 2007). Both anomalies in SST and sea-ice may affect cyclogenesis and the location and intensity of mid-latitude storm tracks. For example, previous research by Godfred-Spenning \& Simmonds (1996) indicated that variations in Antarctic sea-ice may influence cyclogenesis and the movement of extra-tropical cyclones. The southwest Atlantic has been noted as a key area of cyclogenesis (Jones \& Simmonds 1993, Tyson \& Preston-Whyte 2000), where the systems initially develop and then track in an eastwards direction towards the ocean area south of South Africa. Since most extratropical cyclones occur between 50 and $70^{\circ} \mathrm{S}$, it is likely that anomalies in seaice concentration in the Weddell Sea region may influence the formation and movement of these systems towards South Africa.

To assess potential mechanisms, composites of circulation anomalies for anomalously wet and dry winters were constructed. For brevity, plots are shown as wet minus dry composites. Fig. 3 shows the $500 \mathrm{hPa}$ geopotential height composite in which a strong cyclonic anomaly over and upstream of western South Africa is evident, together with another cyclonic anomaly in the cyclogenesis region east of Drake Passage. In addition, $500 \mathrm{hPa}$ height composites were made for high minus low sea-ice years, defined using the 2 areas prominent in Fig. $2\left(0\right.$ to $30^{\circ} \mathrm{E}$, and the Weddell Sea/Drake Passage). In both cases (not shown), the results were similar to those illustrated in Fig. 3, further reinforcing the linkage between sea-ice anomalies and those in geopotential height over the South Atlantic/South African region. The cyclonic anomaly over western South Africa (Fig. 3) leads to increased low-level westerly moisture flux (not shown) from the subtropical South Atlantic towards western South Africa, consistent with wetter conditions there. In addition, there is some evidence of a Rossby wave train of positive and negative departures in geopotential height extending across the South Pacific and South Atlantic towards South Africa.

The cyclonic anomaly over the southeast Atlantic and its extension towards that existing east of Drake Passage suggests that not only are conditions more favourable for storm intensification on approaching western South Africa, but that the mid-latitude storm track was shifted anomalously far north in the region during the wet winters. This suggestion is reinforced 

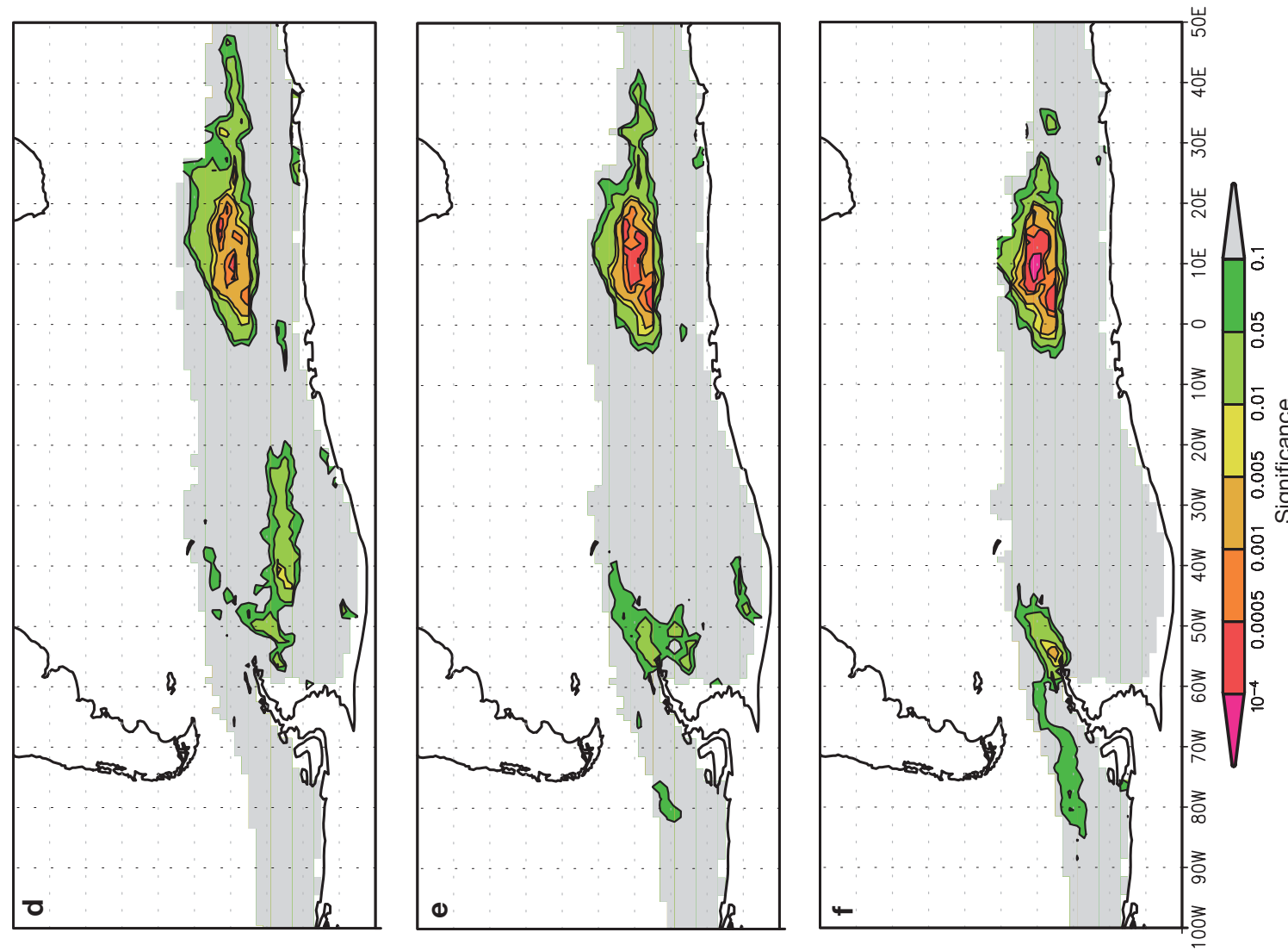

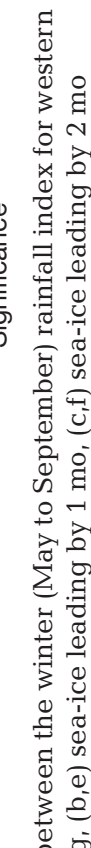
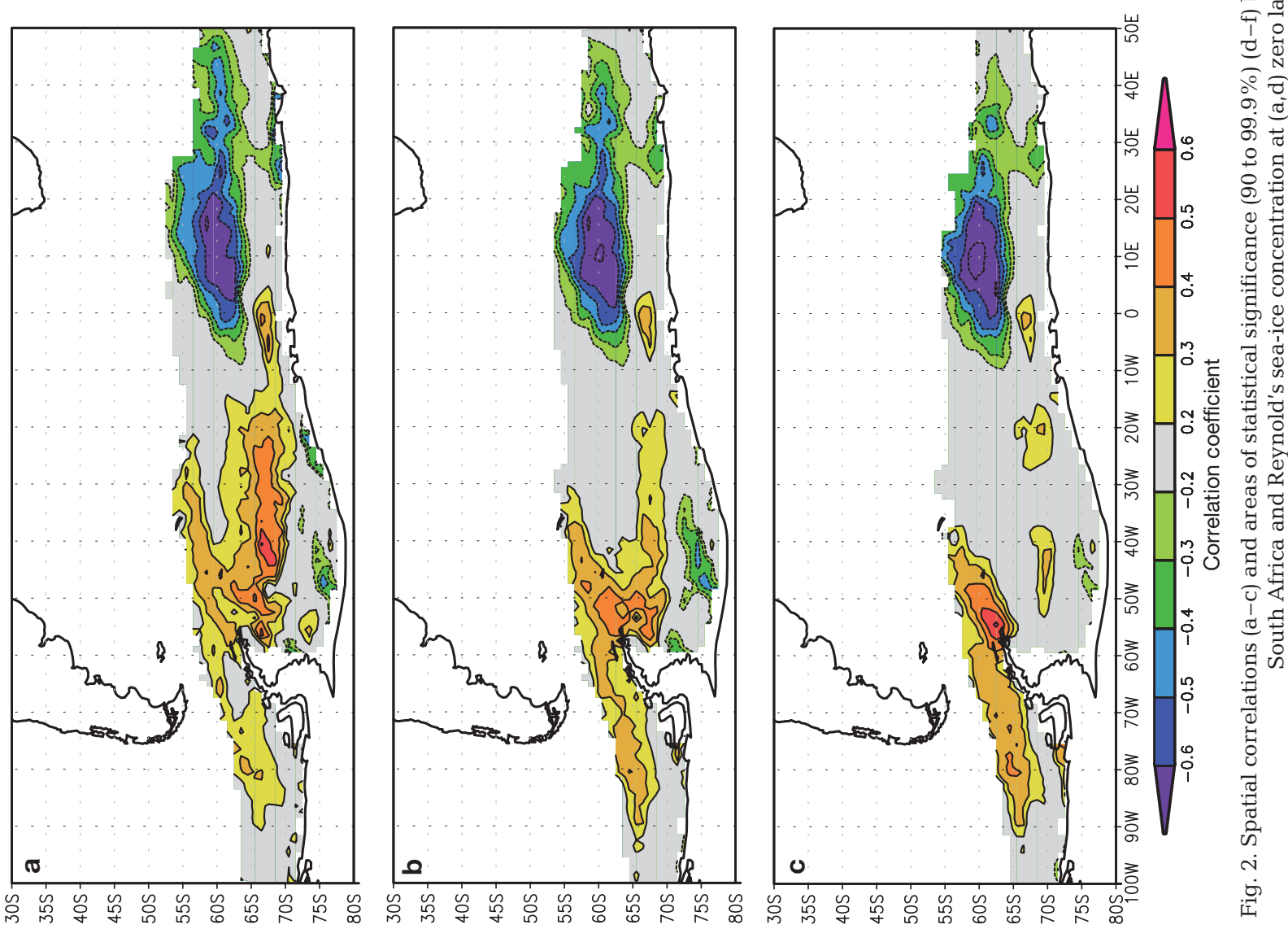


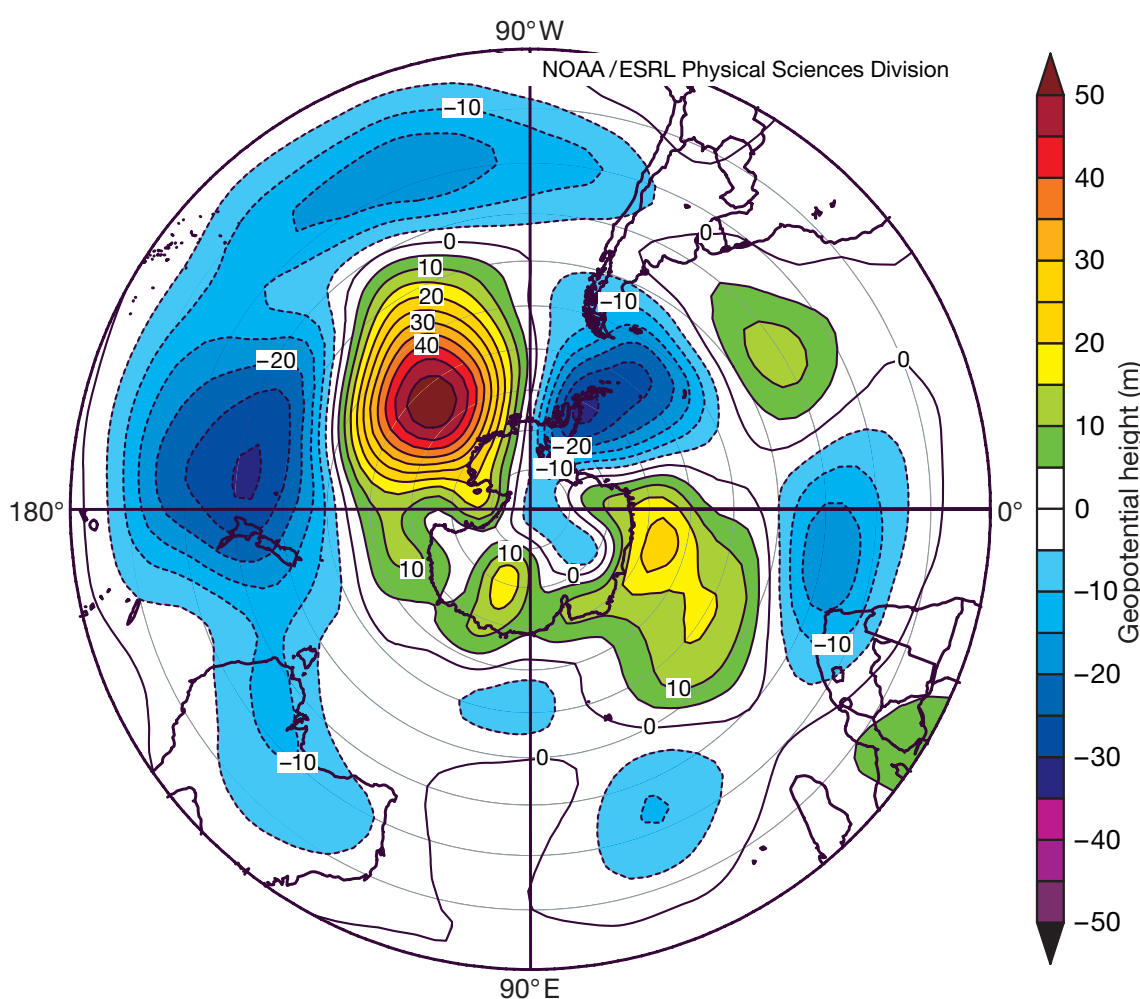

Fig. 3. Composite of $500 \mathrm{hPa}$ geopotential height derived for wet minus dry winters

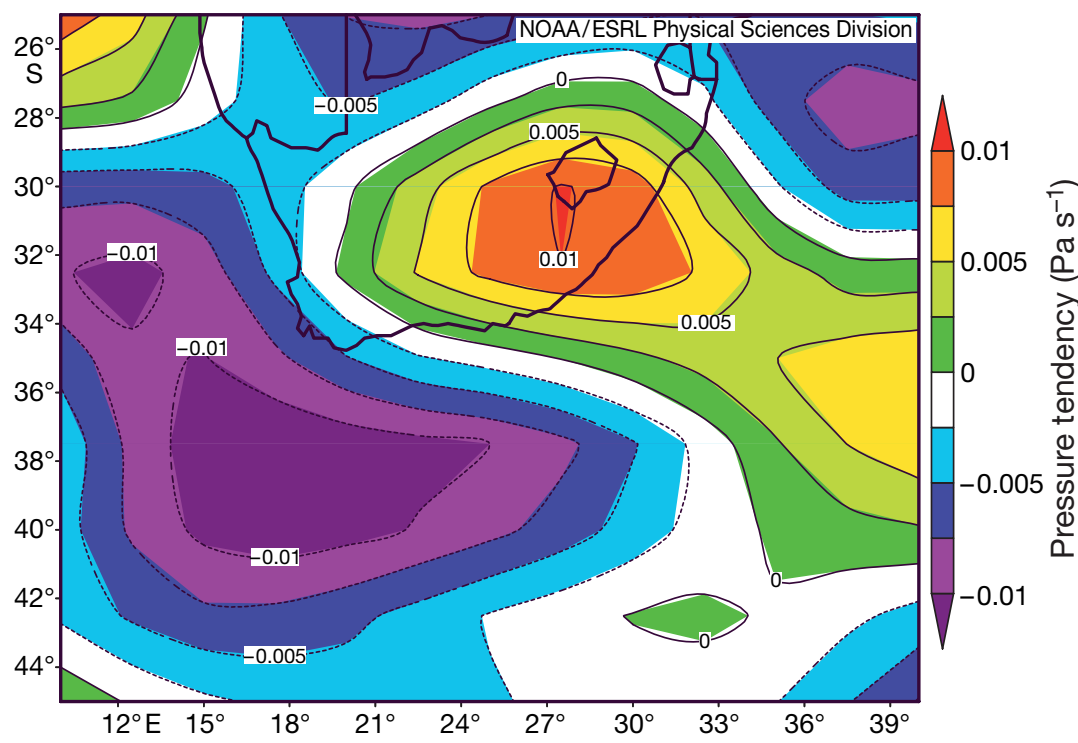

Fig. 4. Composite of pressure tendency at $850 \mathrm{hPa}$ derived for wet minus dry winters. Negative areas indicate relative uplift

by the pressure tendency field (Fig. 4), which shows a large area of strong relative uplift (i.e. negative anomalies in pressure tendency) over and upstream of western South Africa, and relative cyclonic vorticity (not shown) over the southeast Atlantic and stretching west across most of the basin. Relative low-level convergence (not shown) is evident over the southeast Atlantic, implying more favourable conditions for storm intensification upstream of western South Africa during wet winters. In addition, the low level thickness field (Fig. 5) indicates a large area of reduced thickness over western South Africa and upstream across the South Atlantic during wet winters. Since reduced thickness at low levels implies that the lower atmosphere is colder, and therefore less able to hold moisture, the implication of Fig. 5 is increased precipitation over western South Africa and adjoining areas. In addition, Fig. 6 implies that the subtropical jet is shifted north and strengthened over the southeast Atlantic, consistent with a northward shifted storm track and wetter conditions. Fig. 6 also suggests that the polar jet is stronger in the wet winters. Furthermore, NCEP re-analyses indicate enhanced precipitable water over western South Africa, stretching upstream over the subtropical South Atlantic (not shown).

Figs. 3, 5 \& 6 also imply that the wet winters are associated with enhanced baroclinicity in the mid-latitude South Atlantic, which acts to strengthen frontal systems approaching western South Africa, and hence leads to increasing winter rainfall. In addition to changes in sea-ice concentration being linked with changes in storm tracks and thus rainfall, SST anomalies over the South Atlantic may also influence mid-latitude storm tracks and winter rainfall over western South Africa (Reason \& Jagadheesha 2005). Fig. 7 shows the composite wet minus dry SST pattern, which indicates an area of cool (warm) SST anomaly north of the positive or increased (negative or decreased) sea-ice correlation illustrated in Fig. 2. Thus, the mid-latitude SST anomalies appear to work in the same direction as the sea-ice concentration (i.e. reinforce them). This situation might be expected if the mechanisms driving the sea-ice variability also impact on the mid-latitude ocean areas further north, because a decrease (increase) in sea-ice concentration may lead to warmer (cooler) SSTs owing to the oceans underneath the sea-ice being warmer than they otherwise would be. 


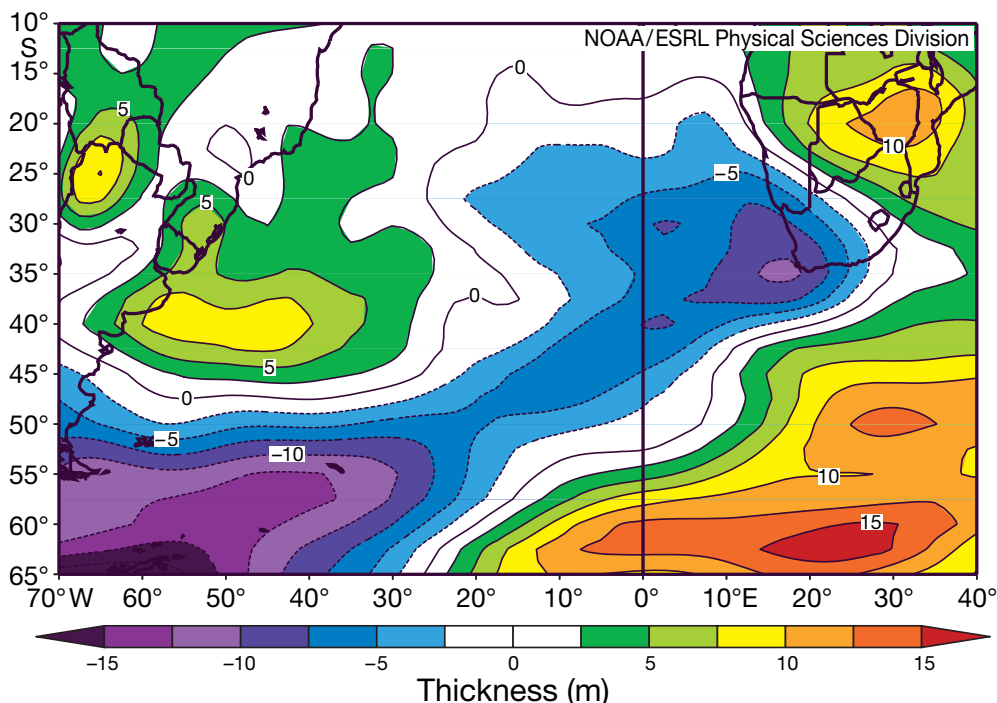

Fig. 5. Composite of the thickness of the 1000-500 hPa layer derived for wet minus dry winters

Further north, a warm-cold SST pattern in the western and central subtropical South Atlantic, similar to that in Fig. 7, was shown by Reason \& Jagadheesha (2005) to lead to increased winter rainfall over western South Africa when the UKMO Hadley Centre Atmospheric Model 3 (HadAM3) General Circulation Model (GCM) was forced by an idealisation of this pattern. Based on their GCM results and other analyses, Reason \& Jagadheesha (2005) argued that the cool anomalies in the central South Atlantic (as seen in Fig. 7) act to increase the baroclinicity between the tropics and the midlatitudes of the storm track approaching western South Africa. Furthermore, a cool anomaly dynamically acts like elevated orography (Gill 1982), implying that a west-

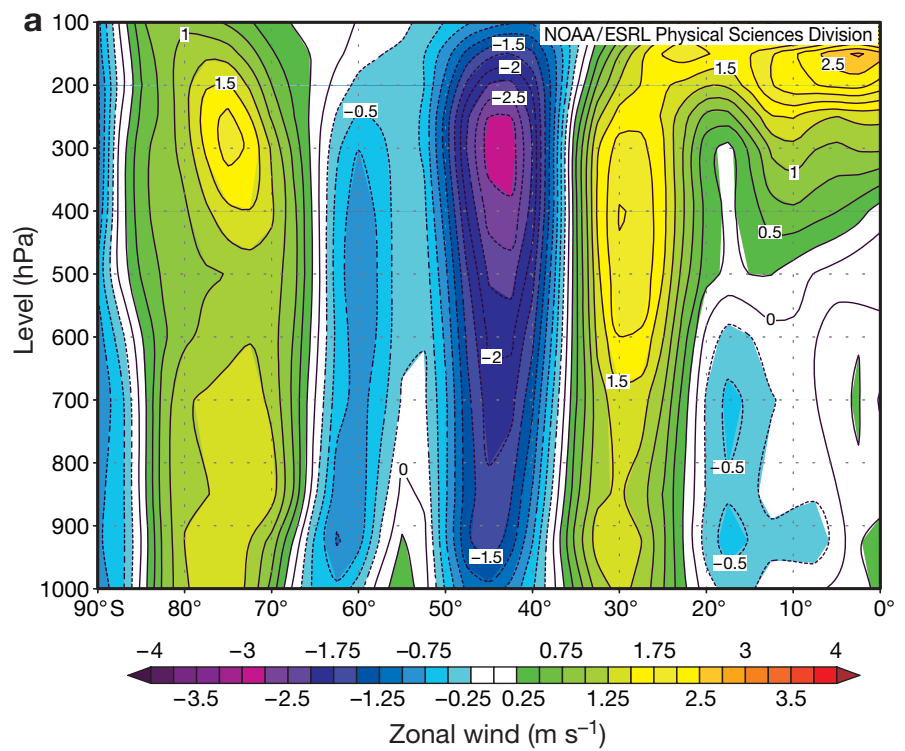

erly flow will be deflected toward the equator to conserve potential vorticity. The same argument can be applied to the cool SST anomaly and enhanced sea-ice concentration in the far southwest Atlantic, to support the inference that the westerly storm track will be shifted further north in this region, as well as to suggest that polar (as opposed to mid-latitude) depressions that do not usually influence western South Africa are more likely to have an impact in this case. This inference is supported by NCEP re-analyses (not shown) that indicate substantially stronger mid-level westerlies in the west and central South Atlantic in the 40 to $60^{\circ} \mathrm{S}$ band.

Peixoto \& Oort (1992) suggested that the cooling (warming) of the sea-ice/open ocean boundary should result in a stronger (weaker) near-surface meridional temperature gradient, which is known to affect cyclogenesis. Thus, the area of increased sea-ice concentration (Fig. 2) and cooler SST (Fig. 7) in the Weddell Sea and Drake Passage region would be favourable for increased cyclogenesis in the far southwest Atlantic, and hence wetter winters over western South Africa, as these systems track towards the South African sector of the Southern Ocean.

In summary, analysis of circulation patterns reveals a consistent picture of a northward-shifted and stronger subtropical jet, increased baroclinicity in the midlatitude South Atlantic, and enhanced cyclonic conditions over and southwest of western South Africa during the wet winters relative to those that are anomalously dry.

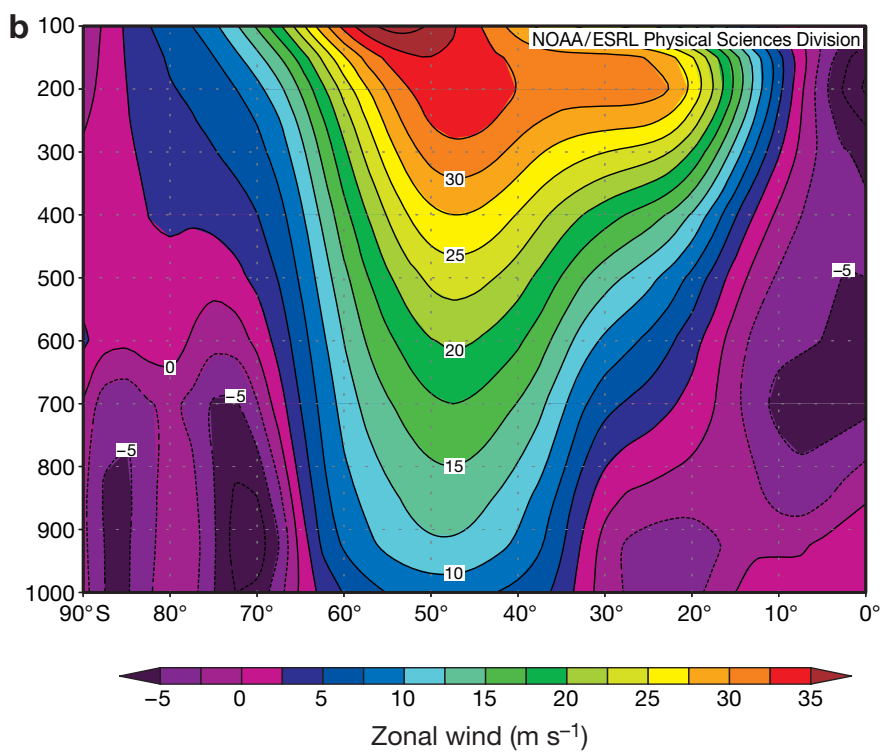

Fig. 6. (a) Composite of a transect of zonal wind along $10^{\circ} \mathrm{E}$, upstream of the west coast of South Africa, derived for wet minus dry winters. (b) Climatological zonal wind along $10^{\circ} \mathrm{E}$ 


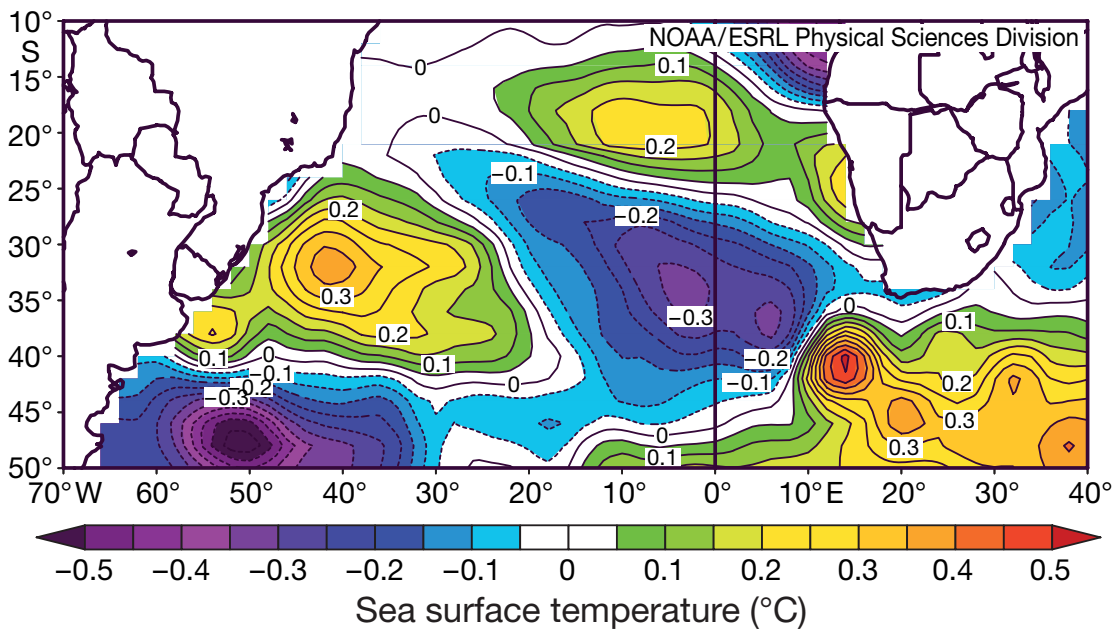

Fig. 7. Composite of SST derived for wet minus dry winters

(1925-26, 1930-31, 1940-41, 1941-42, $1957-58,1963-64,1965-66,1972-73$, 1982-83, 1986-87, 1991-92, 1994-95, 1997-98, 2002-03) and likewise the set of La Niña events $(1924-25,1933-34$, 1938-39, 1942-43, 1949-50, 1954-55, $1955-56,1970-71,1973-74,1975-76$, 1988-89, 1995-96, 1998-99, 1999-00, 2000-01) includes wet, dry and near-average winters over western South Africa.

Carleton (2003) suggested that Wave Number 3 variations related to the Pacific-South-America (PSA) pattern help teleconnect ENSO impacts to the South Pacific/South Atlantic sector. Recent research by Colberg et al. (2004) indicated that the PSA and Wave Number 3 impacts extend right across the South Atlantic to South Africa. Note that there

\section{POTENTIAL RELATIONSHIPS WITH ENSO}

Focus has been placed here on the last 2 decades, which mark the period for which more reliable satellite-derived sea-ice data are available. It should be noted that in addition to the interannual variability investigated here, there is evidence of decadal to multidecadal variability in both the rainfall (Reason \& Rouault 2002) and the mid-latitude atmospheric circulation (e.g. Jones \& Allan 1998, Mo 2000, Reason 2000). As a result, it is possible that the sea-ice/rainfall relationships examined in this study may be modulated on longer time scales. Many climate modes in the Southern Hemisphere, such as ENSO (El Niño Southern Oscillation), the Antarctic Oscillation/Southern Annular Mode, the Antarctic Circumpolar Wave, and the semi-annual oscillation, show variability on decadal and longer scales (e.g. Meehl et al. 1998, Walland \& Simmonds 1999, Mo 2000, Reason et al. 2000, Allan et al. 2003), and this variability may impact the seaice/rainfall relationships discussed here.

ENSO is known to have a significant influence on Antarctic sea-ice (e.g. Simmonds \& Jacka 1995, Yuan \& Martinson 2001, Carleton 2003), and this may impact on the sea-ice/rainfall relationship. However, it should be noted that the set of anomalously wet and dry years derived from Fig. 1 represents El Niño, La Niña and neutral years in each case. Furthermore, in contrast to the summer rainfall region (eastern and northern South Africa), the impacts of ENSO on the winter-rainfall-dominated west coast region analysed here are not coherent or robust (Reason et al. 2000, 2002). For example, South African Weather Service rainfall data indicates that the 10 wettest winters from 1921 to 2004 represented neutral, El Niño and La Niña years, as did the 10 driest winters. In addition, the set of El Niño events since 1920 are some indications of a PSA signal in the wet minus dry 500 hPa geopotential height anomalies (Fig. 3).

To assess how the anomalies in sea-ice may or may not be related to ENSO, composites of these anomalies are shown for the wet minus dry winters (Fig. 8a), El Niño minus La Niña for the winters before the mature phase (onset years) (Fig. 8b), and for El Niño minus La Niña for the winters after the mature phase (mature years) (Fig. 8c). Note that onset years refers to the year of a given ENSO event when the tropical Pacific SST anomaly first evolves (e.g. 1982), and mature years refer to the following year (e.g. 1983). There are some similarities in sea-ice anomaly patterns around Antarctica for each case, but the wet minus dry composite shows the most obvious ice anomaly pattern associated with wet South African winters: namely, a strong contrast between positive anomalies in the Weddell Sea/ Antarctic Peninsula region and negative anomalies in the 0 to $30^{\circ} \mathrm{E}$ sector. This strong contrast is also clearly evident if only neutral years are used to construct the wet minus dry composite (not shown), suggesting that the signal is robust and not solely a feature of ENSO. Note that these contrasting areas are similar to the poles associated with the Antarctic Dipole (western Amundsen Sea and central Weddell Sea; Yuan \& Martinson 2001). Sea-ice extent in these areas was identified by Yuan \& Martinson (2001) as being the most sensitive in the Antarctic to atmospheric Rossby Wave forcing generated by anomalous tropical convection in the Pacific, which may help explain why the patterns in the 2 ENSO composites and the wet minus dry composite are similar, because the latter represents a number of years with large anomalies in atmospheric convection in the tropical Pacific.

Although the sea-ice patterns in the 2 ENSO composites from these sectors are somewhat favourable for 

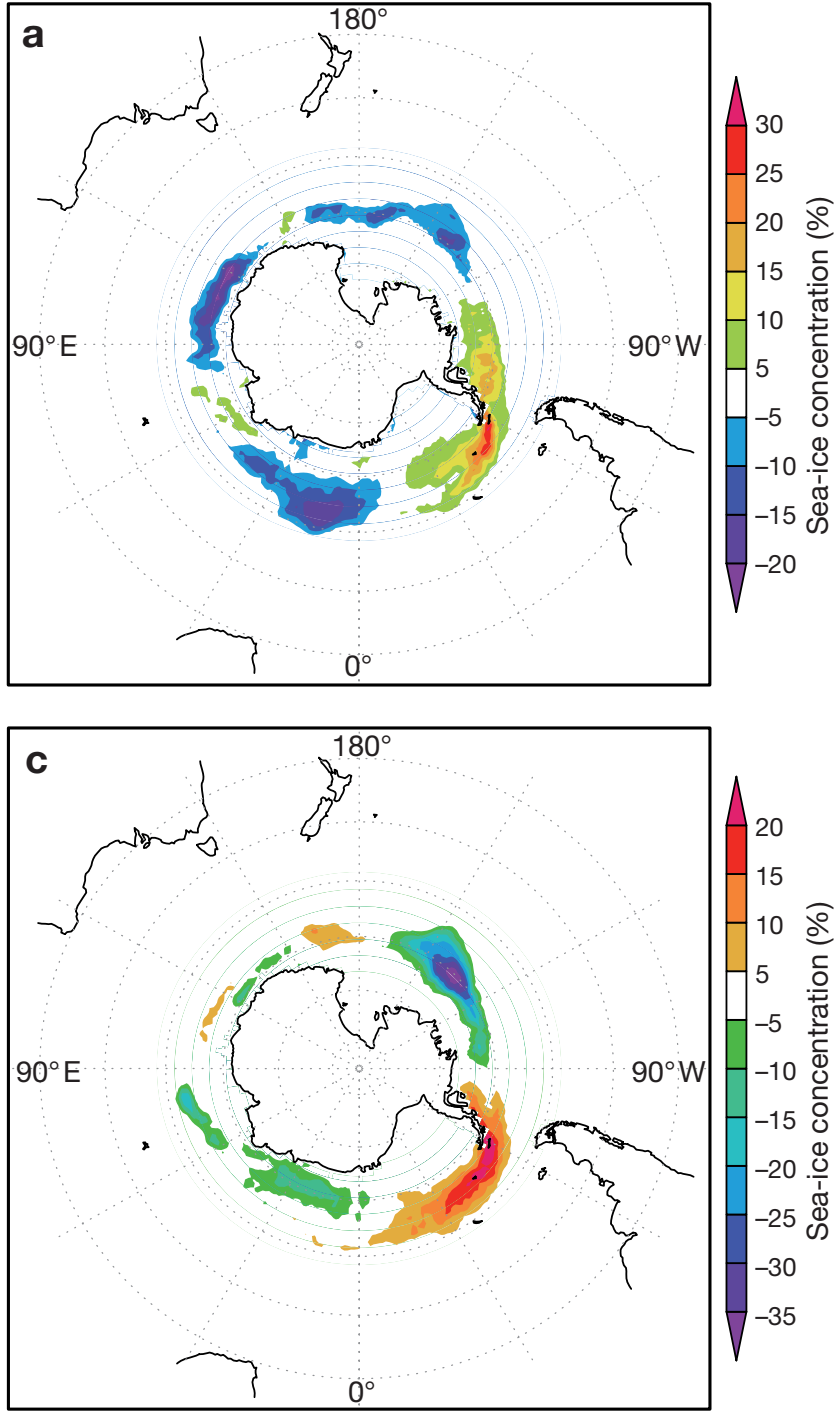

rainfall, the other crucial difference between these years and those of the wet-dry composite is that the ENSO composites of $500 \mathrm{hPa}$ height (Fig. 9) show anticyclonic conditions over southern South Africa and the neighbouring southeast Atlantic, whereas the wetdry composite (Fig. 3) shows a strong cyclonic anomaly in these regions, favourable for intensification of approaching frontal systems. Thus, even if sea-ice conditions in the ENSO composites may have been conducive to increased winter rainfall over southwestern South Africa, this did not necessarily happen owing to the enhanced anticyclonic atmospheric circulation over the country. Consistent with this suggestion, the 2 sets of ENSO composites include a mixture of wet and dry winter seasons.

In an attempt to assess whether the sea-ice anomalies in each case are related to the atmospheric forcing, composite anomalies of meridional and zonal sur-

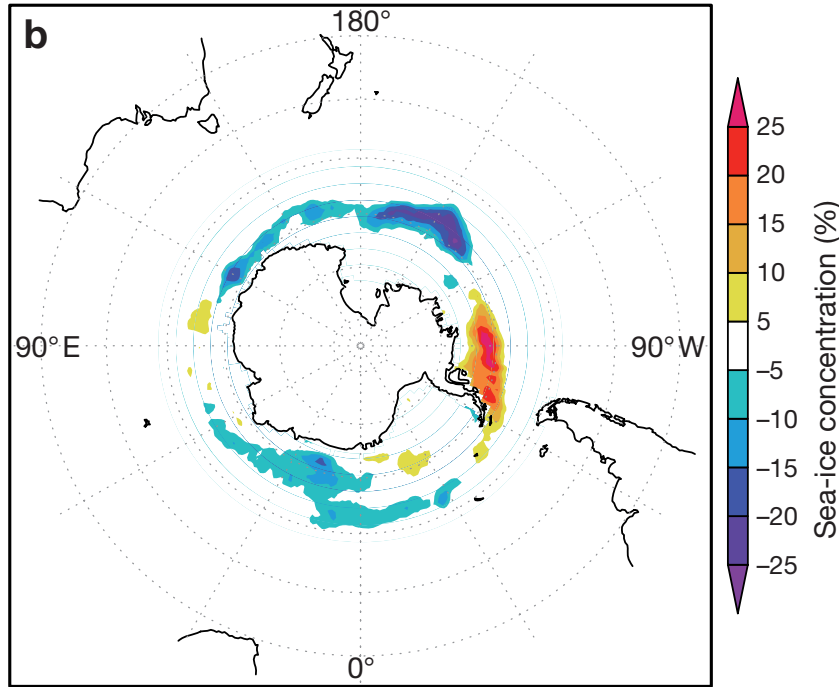

Fig. 8. Composite of sea-ice concentration anomalies derived for (a) wet minus dry winters, (b) El Niño minus La Niña onset years and (c) mature years

face wind and surface wind speed were constructed for the 2 sets of ENSO composites and for the wet minus dry composite. Each set (Fig. 8) shows an increase in sea-ice west of the Antarctic Peninsula together with positive anomalies in the surface meridional wind (Fig. 10), consistent with Harangozo (2006) who showed that meridional-wind-induced drift in this region strongly influenced ice extent. The link between positive sea ice anomalies and meridional wind anomalies also exists just east of the peninsula. A direct relationship between sea-ice and meridional wind also appears to be evident in the Amundsen Sea/eastern Ross Sea (negative anomalies in both ice and wind in each case). In the Weddell Sea, where there are positive ice anomalies, the link with the meridional wind is less clear. Each composite shows weaker zonal winds in this region (not shown) and their magnitudes appear more closely related to those of sea-ice than do the meridional wind anomalies. Note that the influence of the meridional wind on sea-ice extent in this region is not strong (Harangozo 2006).

Thus, the results suggest that there may be a relationship between sea-ice and surface wind anomalies for each composite in the Antarctic Peninsula region, the Amundsen Sea and parts of the Weddell Sea. Although there are some similarities in sea level pressure in each case, more obvious similarities can be seen in the $500 \mathrm{hPa}$ anomaly field (Figs. 3 \& 9), which reveals positive anomalies in the Bellings- 
hausen and Amundsen Seas and negative anomalies near and east or northeast of Drake Passage that seem to be part of a PSA-like Rossby wave train emanating from the tropical Pacific. However, significant differences between the $500 \mathrm{hPa}$ height composites are apparent downstream over the South Atlantic and African sectors, and it is these differences that are associated with the variations in rainfall over western South Africa observed among the 3 composites.

Our results suggest that it is mainly the atmospheric circulation anomalies that are forcing those in sea-ice. However, an argument can be made that some of the circulation anomalies in the wet minus dry composite over the central and western Weddell Sea may be related to the sea-ice anomalies upstream over the Amundsen Sea, and so may be the circulation patterns over the eastern Weddell Sea with the ice anomalies west of the Peninsula. Linear quasi-geostrophic theory and atmospheric GCM runs with mid-latitude South Atlantic SST anomalies (Reason \& Jagadheesha 2005) suggest that the response of the troposphere to a warm (cool) feature is a cyclonic (anticyclonic) anomaly that may be advected downstream by the mean westerly flow. The sea level pressure anomalies for the wet minus dry composite indicate a surface high and low in the Atlantic sector, situated beneath and slightly to the east of the anticyclonic and cyclonic features shown in this sector at $500 \mathrm{hPa}$ in Fig. 3, implying some westward tilt with height as expected. The low pressure anomaly is located east or downstream of the negative sea-ice anomaly in the Amundsen Sea as expected if the response is advected downstream by the strong westerly mean flow (similarly, the high pressure anomaly is located downstream of the positive ice anomaly in the Bellingshausen/western Weddell Sea). However, it is likely that only a fraction of the atmospheric anomalies are generated as a response to the sea-ice, and that other factors such as the response to tropical convection during these years, lower latitude SST patterns and internal variability are also very important. For example, the global SST anomalies of the

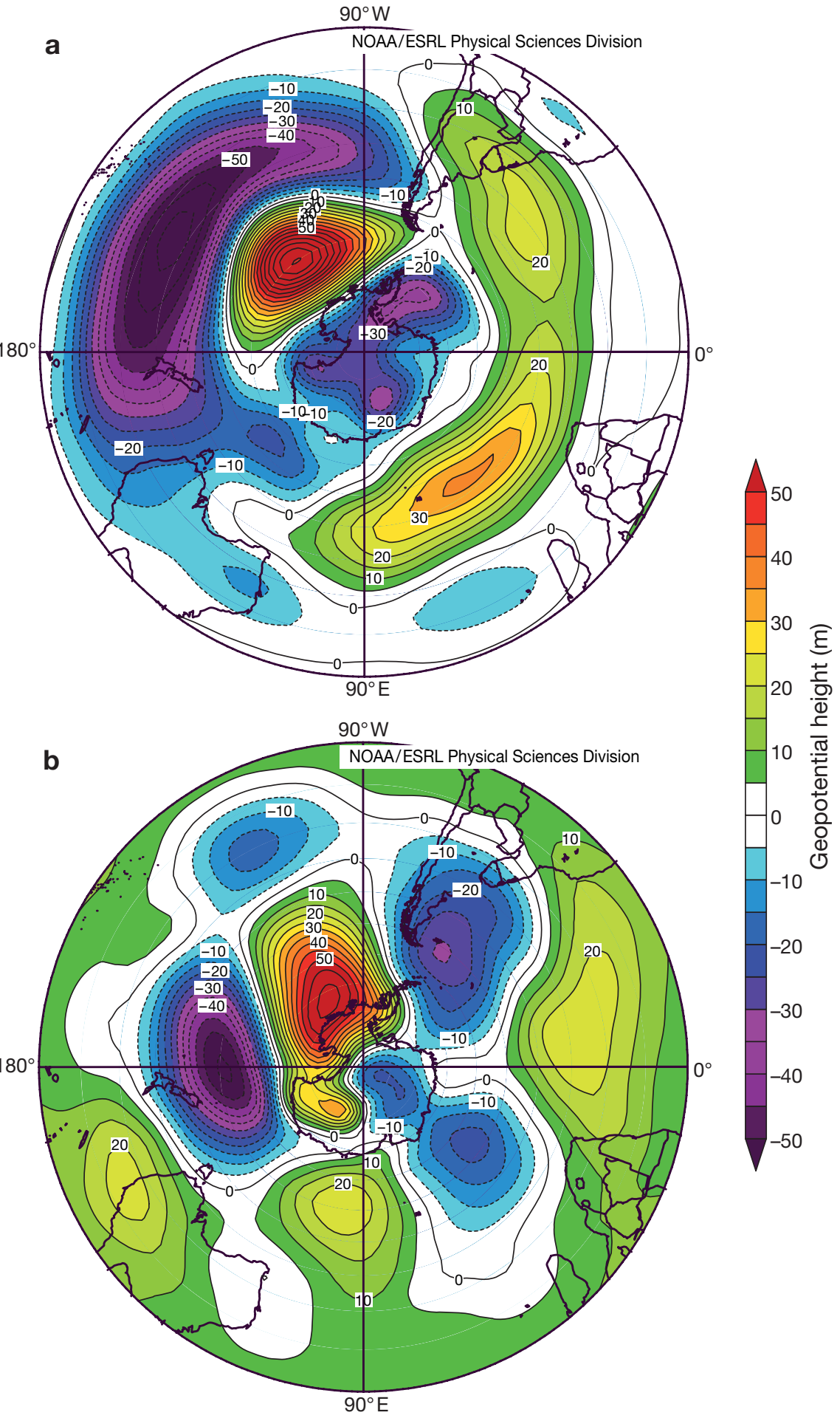

Fig. 9. Composite of $500 \mathrm{hPa}$ geopotential height derived for (a) El Niño minus La Niña onset years and (b) mature years

wet minus dry composite (not shown) indicate a clear El Niño-like pattern in the Pacific, which helps explain why the sea-ice anomalies in Fig. 8 are so similar. 

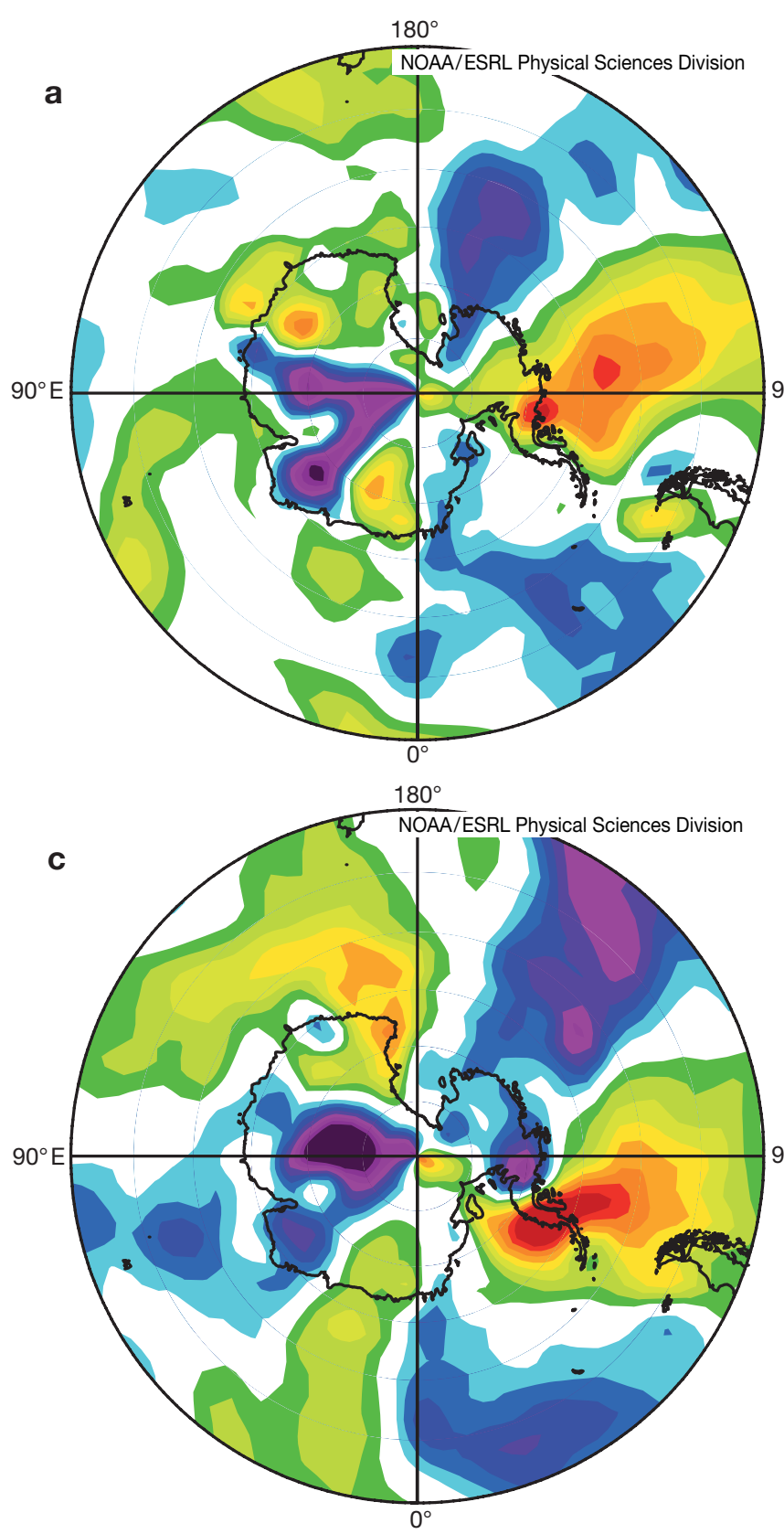

\section{CONCLUSIONS}

Evidence presented here indicates that Antarctic sea-ice, particularly within the South Atlantic sector, is related to winter rainfall over western South Africa. A positive (negative) correlation was found between the rainfall and sea-ice concentration in the Weddell Sea/Drake Passage region (east of the Weddell Sea near the band of 0 to $30^{\circ} \mathrm{E}$ ). The correlations appear to be stronger in early and mid-winter (May to July and June to August) than in late winter (July to September) and, for individual months, in July. In all cases, the patterns in sea-ice are present at least 2 mo in advance of

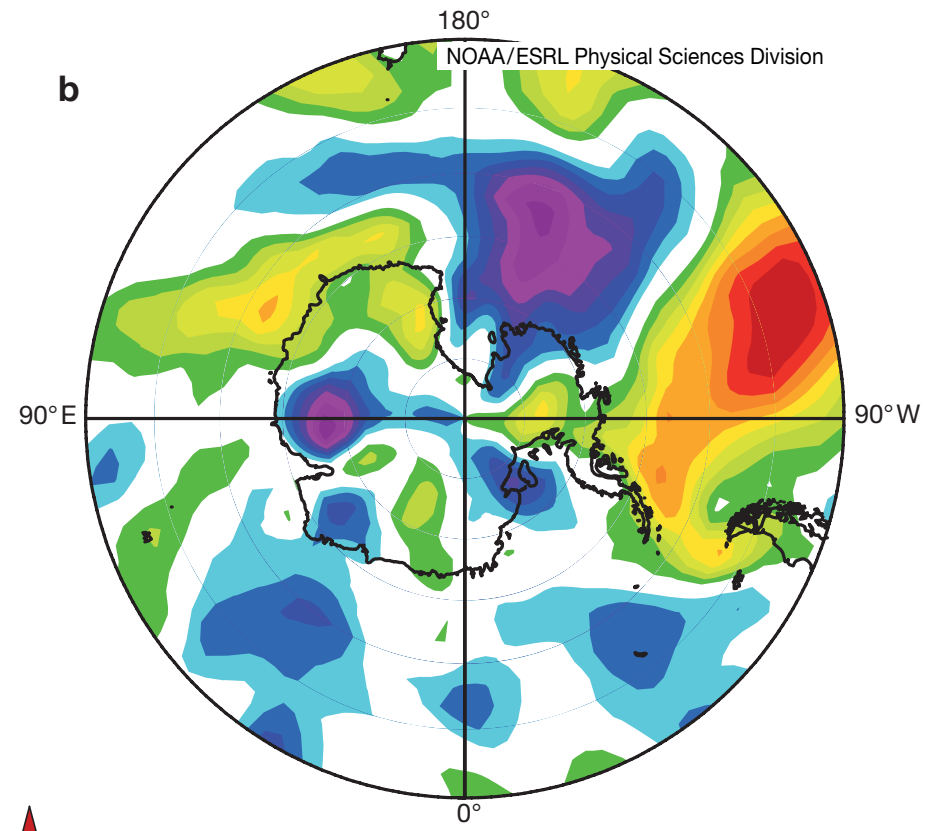

Fig. 10. Composite of meridional wind anomalies derived for (a) wet minus dry winters, (b) El Niño minus La Niña onset years and (c) mature years

the rainfall season, suggesting that there may be some predictability of the winter rainfall based on the state of the sea-ice concentration in the preceeding late summer or autumn.

The mechanisms by which the sea-ice and rainfall are linked appear to involve shifts in the subtropical jet and midlatitude storm tracks with changes in low level vorticity, convergence and uplift over western South Africa and the neighbouring southeast Atlantic Ocean.

It should be emphasized that our results are based on composite analyses and statistical correlations over a relatively short period, and that more detailed investigations using models would be needed to obtain greater confidence in these findings. Given its proximity to 3 highly variable oceans and its remoteness from the core regions of ENSO and the Southern Annular Mode, it is inevitable that the climate variability of South Africa is very complex and influenced by a number of contributing factors. The sea-ice/winter rainfall relationship over western South Africa is one of several that exist, and it is not possible to isolate a single dominant mechanism. However, if appropriately validated, model studies could address the relative contributions of different factors as well as provide a longer period of sea-ice data than the 
23 yr period (1982 to 2004) considered here. Although an argument was presented that sea-ice anomalies upstream in the sector from the eastern Ross Sea east to the Antarctic Peninsula could have contributed to at least some of the atmospheric circulation anomalies over the Weddell Sea and further east, a detailed model study - beyond the scope of the current work-is required to properly assess this possibility. In addition, feedbacks from the atmosphere to the ocean and seaice may be important considerations. To fully investigate the interactions and feedback between the atmosphere, oceans and sea-ice, a coupled model study is needed. Such interactions could have an effect on the outcome of the results; therefore, the results presented here should be viewed with caution.

Acknowledgements. This study represents part of R. Blamey's BSc (Honours) thesis. Some plots were generated on the KNMI Climate Explorer web site (http://climexp.knmi.nl) and others on the Climate Diagnostics Center website (www.cdc.noaa.gov).

\section{LITERATURE CITED}

Allan RJ, Reason CJC, Lindesay JA, Ansell TJ (2003) Protracted ENSO episodes and their impacts in the Indian Ocean region. Deep-Sea Res 50:2331-2347

Carleton AM (2003) Atmospheric teleconnections involving the Southern Ocean. J Geophys Res 108:8080, doi:10.1029/ 2000JC000379

Colberg F, Reason CJC, Rodger K (2004) South Atlantic response to ENSO induced climate variability in an OGCM. J Geophys Res 109:C12015, doi: 10.1029/2004JC002301

de la Mare WK (1997) Abrupt mid-twentieth-century decline in Antarctic sea-ice extent from whaling records. Nature 389: $57-60$

Eicken H, Lemke P (2001) The response of polar sea ice to climate variability and change. In: Lozán JL, Graßl H, Hupfer P (eds) Climate of the 21st century: changes and risks. GEO, Hamburg, p 206-211

Gill AE (1982) Atmosphere-ocean dynamics. Academic Press, New York

Godfred-Spenning CR, Simmonds I (1996) An analysis of Antarctica sea-ice and extratropical cyclone associations. Int $\mathrm{J}$ Climatol 16:1315-1332

Harangozo SA (2006) Atmospheric circulation impacts on winter maximum sea ice extent in the west Antarctic Peninsula region (1979-2001). Geophys Res Lett 33:L02502, doi:10.1029/ 2005GL024978

Hudson DA, Hewitson BC (2001) The atmospheric response to a reduction in the summer Antarctic sea-ice extent. Clim Res 16:79-99

Jones DA, Simmonds I (1993) A climatology of Southern Hemisphere extratropical cyclones. Clim Dyn 9:131-145

Jones PD, Allan RJ (1998) Climate change and long-term variability. Am Meteorol Soc Meteorol Monogr No. 49, p 337-363

Kalnay E, Kanamitsu M, Kistler R, Collins W and 18 others (1996) The NCEP/NCAR 40-year reanalysis project. Bull Am Meteorol Soc 77:437-471

Meehl GA, Hurrel JW, van Loon H (1998) A modulation of the mechanism of the semiannual oscillation in the Southern Hemisphere. Tellus 50A:442-450

Melice JL, Lutjeharms JRE, Goosse H, Fichefet T, Reason CJC
(2005) Evidence for the Antarctic circumpolar wave in the subAntarctic during the past 50 years. Geophys Res Lett 32:L14614, doi:10.1029/2005GL023361

Mo KC (2000) Relationships between low-frequency variability in the Southern Hemisphere and sea surface temperature anomalies. J Clim 13:3599-3610

Peixoto JP, Oort AH (1992) Physics of climate. American Institute of Physics, New York

Reason CJC (2000) Multidecadal climate variability in the subtropics/mid-latitudes of the Southern Hemisphere oceans. Tellus 52A:204-223

Reason CJC, Jagadheesha D (2005) Relationships between South Atlantic SST variability and atmospheric circulation over the South Africa region during austral winter. J Clim 18: 3059-3075

Reason CJC, Rouault M (2002) ENSO-like decadal patterns and South African rainfall. Geophys Res Lett 29(13):1638, doi:10.1029/2002GL014663

Reason CJC, Rouault M (2005) Links between the Antarctic Oscillation and winter rainfall over western South Africa. Geophys Res Lett 32:L07705, doi:10.1029/2005GL022419

Reason CJC, Allan RJ, Lindesay JA, Ansell TJ (2000) ENSO and climatic signals across the Indian Ocean basin in the global context: Part I, interannual composite patterns. Int J Climatol 20:1285-1327

Reason CJC, Rouault M, Melice JL, Jagadheesha D (2002) Interannual winter rainfall variability in SW South Africa and large scale ocean-atmosphere interactions. Meteorol Atmos Phys 80:19-30

Renwick JA (2002) Southern Hemisphere circulation and relations with sea ice and sea surface temperature. J Clim 15:3058-3069

Reynolds RW, Smith TM (1994) Improved global sea surface temperature analyses using optimum interpolation. J Clim 7 : 929-948

Reynolds RW, Rayner NA, Smith TM, Stokes DC, Wang W (2002) An improved in situ and satellite SST analysis for climate. J Clim 15:1609-1625

Simmonds I, Jacka TH (1995) Relationships between the interannual variability of sea ice and the Southern Oscillation. J Clim 8:637-647

Singleton AT, Reason CJC (2006) Numerical simulations of a severe rainfall event over the Eastern Cape coast of South Africa: sensitivity to sea surface temperature and topography. Tellus 53A:355-367

Singleton AT, Reason CJC (2007) A numerical model study of an intense cut-off low pressure system over South Africa. Mon Weather Rev (in press)

Sterl A, Hazeleger W (2003) Coupled variability and air-sea interaction in the South Atlantic Ocean. Clim Dyn 21:559-571

Tennant W (2004) Considerations when using pre-1979 NCEP/ NCAR reanalyses in the southern hemisphere. Geophys Res Lett 31:L11112, doi:10.1029/2004GL019751

Tyson PD, Preston-Whyte RA (2000) The weather and climate of Southern Africa. Oxford University Press, Cape Town

Wadhams P (1994) The Antarctic sea ice cover. In: Hempel G (ed) Antarctic science, global concerns. Springer-Verlag, Berlin, p 45-59

Walland D, Simmonds I (1999) Baroclinicity, meridional temperature gradients, and the southern semiannual oscillation. J Clim 12:3376-3382

White WB, Peterson RG (1996) An Antarctic circumpolar wave in surface pressure, wind, temperature and sea ice extent. Nature 380:699-702

Yuan X, Martinson DG (2000) Antarctic sea ice extent and its global connectivity. J Clim 13:1697-1718

Yuan X, Martinson DG (2001) The Antarctic dipole and its predictability. Geophys Res Lett 28:3609-3612

Submitted: October 11, 2005; Accepted: November 13, 2006

Proofs received from author(s): February 13, 2007 